On the relationship between cognitive style (field-dependence/independence) and translation achievement of Iranian translation students

Keshmandi, Omid

English Department, Imam Reza International University, Iran (omidkeshmandi@yahoo.com) Akbari, Omid

English Department, Imam Reza International University, Iran (Omidakbari@imamreza.ac.ir) Ghonsooly, Behzad

Department of English Language and Literature, Ferdowsi University of Mashhad, Iran ( $\underline{\text { Ghonsooly@um.ac.ir) }}$

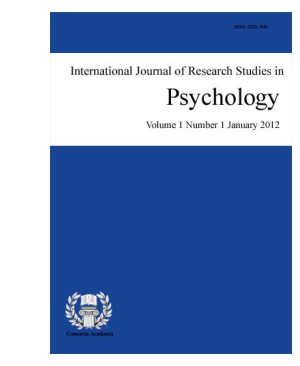

ISSN: $2243-7681$ Online ISSN: $2243-769 \mathrm{X}$

OPEN ACCESS

\title{
Abstract
}

The present study examines the relationship between Cognitive style Field dependence/independence (FDI) and translation achievement. The participants included 100 (73 female and 27 male) BA senior students studying English translation as their major at Imam Reza International University and Khayyam Institute of higher education. Both male and female students responded to the Group Embedded Figures Test (GEFT) .They were divided into field-dependent and field-independent groups according to the scores gained in the GEFT. The results of the study indicated that students' Cognitive style FDI have a positive and significant relationship with their translation achievement. Field Independents outperformed Field Dependents in their translation task and it also revealed that as translation students' Cognitive style FDI increases, their translation achievement increases significantly. Cognitive style as psychological construct, has been the focus of attention in recent decades, therefore, the findings of current study will result in higher translation achievement of students and will help translation instructors plan better for the improvement of their students.

Keywords: cognitive style; translation achievement; field dependence; field independence 


\section{On the relationship between cognitive style (field-dependence/independence) and translation achievement of Iranian translation students}

\section{Introduction}

Human beings, throughout history, have made efforts to take advantage of various methods of communication with the purpose of using the knowledge of other countries and nations to keep this knowledge for future generations; therefore, the language has been used to satisfy the very need of communication. Nowadays, communication among many nations with different languages is possible through translation. A short look at the history of translation studies shows the lack of attention on the role of some psychological factors and the effect that these factors can have on translation achievement of translation students. Although a lot of research have been done on different realm of language learning connecting the role of some psychological factors such as cognitive styles (Field dependence and Field independence/FDI) on language acquisition and in the field of psychology, lack of the relationship of these factors with translation achievement of translation students of universities is obvious. Translation has a lot in common with other sciences particularly psychology. As Baker (1998, p. 4) points out translation is a separate academic discipline which, "like any young discipline, needs to draw on the findings and theories of the other related disciplines in order to develop and formulate its own methods."

Apparently translation studies are a major that needs to be improved by applying different psychological factors like cognitive style FDI. By exploring the level of Cognitive style FDI of a translator; it would be possible to address their training requirements in order to make them perform enthusiastically and productively. This study aims at investigating the relationship of Cognitive style (FDI) on translation achievement. Cognitive style historically has referred to a psychological dimension representing consistencies in an individual's manner of cognitive functioning, particularly with respect to acquiring and processing information (Ausburn \& Ausburn, 1978) and are defined as stable attitudes, preferences, or habitual strategies that determine individuals' modes of perceiving, remembering, thinking, and problem solving (Messick, 1986).

The most widely researched dimension of cognitive style is field dependence/independence (FDI). Field independent people tend to analyze the information and restructure it according to their needs and they are good at identifying objects or details; On the other hand, Field dependent people tend to perceive information and take it as it is presented to them and they are more sensitive to external clues and also they are less able to view things separate from the overall environment. Few researches have recently been conducted on the concept of Cognitive style and language acquisition or teaching and on the concept of cognitive style and learning. Obviously, cognitive style FDI is relatively new notion in the field of Translation Studies; therefore, it is considered an essential need to be explored. The present study sought to link the relationship between cognitive style FDI level of translators and their translation achievement. This study is designed to address the following research questions:

Q1: Is there any significant relationship between translation students' Field-dependence/independence cognitive style and their translation achievement?

Q2: Is there any significant difference in the translation achievement of students with higher levels of cognitive style FDI and those with lower levels of cognitive style FDI?

\subsection{Research Null Hypotheses}

$>$ H1: There is no significant relationship between translation students' Field dependence/independence cognitive style and their translation achievement. 
On the relationship between cognitive style and translation achievement of Iranian translation students

$>\quad \mathrm{H} 2$ : There is no significant difference in the translation achievement of students with higher levels of cognitive style FDI and those with lower levels of cognitive style FDI.

\section{Review of Literature}

\subsection{Cognitive style}

According to O'brien, Butler, and Bernald (2001), Cognitive styles, comparing to other variables such as the affective and physiological factors, seem to be the most relevant variables to those associated with academic achievement. Cognitive style referring to an individual's habitual way of perceiving, remembering, thinking and problem solving was originally proposed by Allport (1937). Messick (1984) defined cognitive styles as information processing habits representing the learner's typical mode of perceiving, thinking, problem solving and remembering. Ngeow (1999, as cited in Kheirzadeh \& Kassaian, 2011), summarized the main benefits of cognitive styles as follow:

$>\quad$ Learners who are conscious of their style make better use of their learning opportunities.

$>\quad$ Learners learn better when they are provided with learning opportunities that enhance and extend their learning preferences.

$>\quad$ Learners work better with new learning styles when they are given guided opportunities to practice them.

Many cognitive styles have been identified and studied in the literature since 1950s for instance, Ausbel (1968) identified 18 different types. Hill (1972) defined 29 different factors. Riding and Cheema (1991) identified 30 different types and among reflective-impulsive (Kagan et al., 1964), holistic-serial (Pask \& Scott, 1972), verbalizer-imager (Riding \& Cheema, 1991), holistic-analytic (Riding \& Cheema, 1991) and field dependency (Witkin et al., 1977), field dependency received the most attention among researchers. Field dependency describes two contrasting ways of processing information named field dependence and field independence. Those individuals who are field dependent, have difficulty in separating incoming information from its contextual surroundings and are more likely to be influenced by external cues, on the other hand, field independent individuals have less difficulty in separating the most important information from its context, and are more likely to be influenced by internal cues (Riding \& Chema, 1991).

Several researches have been done to investigate the effect of field dependence/independence on different tasks particularly language learning. And these studies showed some beneficial points about field dependent/independent students and their differences in mastering language skills. For instance, Khodadady and Zeynali (2012) explored the relationship between field-dependence/independence cognitive style and listening comprehension ability. In their findings, Field-independent participants outperformed field-dependent participants in IELTS listening comprehension and all of the listening tasks. Another research which was done on the realm of language learning was Kheirzadeh and Kassaian (2011) research of Field-dependence/independence as a Factor Affecting Performance on Listening Comprehension Sub-skills: the Case of Iranian EFL Learners. The results of their research showed that there was no difference in the performance of FD and FI students on general listening comprehension. Dabaghi and Goharimehr (2011) reported significant differences in students' learning of grammar by two teaching methods of discrete-point and integrative teaching on one hand and the relationship between learning styles of field dependence/independence and these methods on the other hand.

In other areas related to learning and education, a study was done by Jack Block et al. (1998) to examine the relationship between Parental teaching strategies and children's cognitive style. A total of 83 mothers and 74 fathers and their respective 4-year-old sons or daughters participated in the research. Distinctive differences in parental teaching strategies were observed dependent on the child's Field Dependence/Independence status. 
Parents of FD children were controlling and quite critical of their children's performance. And in another study which was not related to education, Jon-Chao Hong et al. (2012) examined the Effects of cognitive style on digital jigsaw puzzle performance. The findings showed that digital jigsaw puzzle scoring was positively correlated with Field Independent. Field Independent students achieved significantly higher scores than FD students.

\subsection{Translation}

Human beings, throughout history, have made efforts to take advantage of various methods of communication with the purpose of using the knowledge of other countries and nations to keep this knowledge for future generations; therefore, the language has been used to satisfy the very need of communication. Nowadays, communication among many nations with different languages is possible through translation.

To evaluate a translation work, experts in the fields of translation try to come up with certain criteria whose application would lead to better assessment of translation work and more comprehensive feedback for observing better translation. Therefore, such assessment area is 'one where a more expert writer or a marker of translation examination or a receiver of a professional translation addresses a less expert reader or usually a candidate for examination or a junior professional translator (Munday, 2008). There are different methods of assessment for students' translation used by teachers of translation. On the criteria related to improvement of translation assessment, Waddington (1999-2001) examined two kinds of methods typically used at European universities based on error analysis and those based on a holistic approach. In his paper, four methods were discussed as follow:

"-Method A which is based on error analysis and possible mistakes and are grouped under the following headings:

$>$ Inappropriate renderings which affect the understanding of the source text; these are divided into eight categories: contresens, faux sens, nonsens, addition, omission, unresolved extra-linguistic references, loss of meaning, and inappropriate linguistic variation (register, style, dialect, etc.).

$>$ Inappropriate renderings which affect expression in the target language; these are divided into five categories: spelling, grammar, lexical items, text and style.

$>$ Inadequate renderings which affect the transmission of either the main function or secondary functions of the source text."

In each of the categories a distinction is made between serious errors ( -2 points) and minor errors ( -1 point). There is a fourth category which describes the plus points to be awarded for good (+1 point) or exceptionally good solutions ( +2 points) to translation problems.

Method B is also based on error analysis and was designed to measure the negative effect of errors on the overall quality of the translations. The corrector first has to determine whether each mistake is a translation mistake or just a language mistake; this is done by deciding whether or not the mistake affects the transfer of meaning from the source to the target text: if it does not, it is a language error (and is penalized with -1 point); if it does, it is a translation error (and is penalized with -2 points).

Method C in Waddington's methods of assessment is a holistic method of assessment. In this method, $0-10$ is considered for the corrector to award the higher mark to the candidate who fully meets the requirements of a particular level and the lower mark to the candidate who falls between two levels but is closer to the upper one.

And the last method introduced by Waddington consists of combining error analysis Method B and holistic Method C. 


\section{Methodology}

\subsection{Participants}

This study was done in Mashhad, Iran. The participants of the study consisted of 100 senior translation students of Imam Reza International University and Khayyam Institutes of Higher Education. All of them were required to have passed the basic courses in translation field namely "Principles and Methodology of Translation" and "Theories of Translation". The participants were both male (27\%) and female (73\%). They were given Cognitive styles FDI questionnaire and on the basis of the results, they were classified into Field Independent and Field Dependent.

\subsection{Instrumentation}

The GEFT - The group embedded figure test (GEFT) which was developed by Witkin, Oltman, and Raskin (1971) was used in this study to group students as Field dependent and Field independent. This test contains three sections. There are 25 items in GEFT and during 15 minutes, participants were asked to find the simple form in the complex figure and trace it in pencil directly over the lines of the complex figure. The first section is used for practice. The participants were divided into field-dependent and field-independent groups according to Ling and Salvendy's method (2000).

Rendering Text - In the first step, a general text was selected by the researcher, the supervisor and by an examiner. The text was taken from a book named "Techniques of Advanced Translation" by Dr. Alaeddin Pazargadi which was published in spring 1378. Then text was examined by the researcher and supervisor and also it was examined by an examiner in the given field and since the text is about Language communication and it includes some aspects of Cognitive style, it could be a good choice for the translation task. Therefore after being examined, it was chosen for the related purpose.

\subsection{Data collection}

In the first step, after getting permission from the instructors, the researcher visited the classes to administer The Group embedded figure test (GEFT). First, they were introduced to the Group embedded figure test. Then the students were asked to translate the general text from English to Persian. While the participants were answering the questionnaire, they were served juice and cookies to help them focus better on the questionnaire items. Students were asked to find the simple form in the complex figure and trace it in pencil directly over the lines of the complex figure during 15 minutes. After collecting all data and calculating GEFT, the students were divided into Field dependent/independent.

\subsection{Data Analysis}

In order to answer the first research question, the Pearson Correlation formula was used. And to answer the second research question an independent sample t-test was used. The participants in GEFT were divided into field-dependent and field-independent groups according to Ling and Salvendy's method (2000). Section one of GEFT includes seven complex figures and sections two and three include nine complex figures each and the seven beginning figures were for practice and familiarizing students with the test; therefore, the maximum score would be 18. Those students who gained score 11 or more were grouped as FI (field-independent) and those gaining less than 11 were grouped as FD (field-dependent) (Khodadady \& Zynali, 2012). Moreover, the rendering text was scored by the researcher and an examiner with the degree of MA in translation. They scored the text for naturalness and accuracy and then they had a mean score for both of the given items. The text was scored based on Waddington's model of translation assessment (2001). 


\section{Results}

In Table 1, Minimum, Maximum, Mean and Standard Deviation of the variables of students' translation achievement, Cognitive Style is presented. Minimum, Maximum, Mean and Standard Deviation of the variables for students' translation achievement are 1, 8, 3.92, and 1.3 respectively. Minimum, Maximum, Mean and Standard Deviation of the variables of students' Cognitive Style are 1, 25, 17.75, and 4.8 respectively.

Table 1

Descriptive Statistics variables

\begin{tabular}{lccccc}
\hline \multicolumn{1}{c}{ Treatment group } & $\mathrm{N}$ & Minimum & Maximum & Mean & Std. Deviation \\
\hline Translation achievement & 100 & 1.00 & 8.00 & 3.92 & 1.3 \\
Cognitive Style & 100 & 1.00 & 25.00 & 17.75 & 4.8 \\
\hline
\end{tabular}

To test the normality of the variables, Kolmogorov-Smirnov Test was used in the study to test if the variables have the level of normal distribution. If the variables are normal, the parametric tests will be used and if not, nonparametric tests will be useful for the given purpose. The results of Kolmogorov-Smirnov Test are shown in Table 2.

\section{Table 2}

One-Sample Kolmogorov-Smirnov Test

\begin{tabular}{lcc}
\hline & Translation achievement & Cognitive Style \\
\hline $\mathrm{N}$ & 100 & 100 \\
Kolmogorov-Smirnov Z & 1.078 & .913 \\
Asymp. Sig. (2-tailed) & .14 & .375 \\
\hline
\end{tabular}

As can be seen in Table 2, since the meaningful level of the test for all the variables is more than 0.05 , the normality assuming of the variables is accepted and all the variables fit the normal distribution. Therefore, parametric tests can be used for testing the hypotheses.

The first research questions deals with the relationship between translation students' Field dependence/independence cognitive style and their translation achievement. To test such relationship Pearson Correlation Test was used.

Table 3

Correlations between Translation achievement and Cognitive style

\begin{tabular}{lcc}
\hline & & Cognitive Style \\
\hline \multirow{2}{*}{ Translation achievement } & Pearson Correlation & $.333^{*}$ \\
& Sig. (2-tailed) & .001 \\
Note *Correlation is significant at the 0.05 level (2-tailed) & $\mathrm{N}$ & 100 \\
\hline
\end{tabular}

Note. ${ }^{*}$ Correlation is significant at the 0.05 level (2-tailed)

As can be seen in Table 3, the meaningful level of Pearson Correlation Test between translation student's Cognitive style FDI and his/her translation achievement is 0.333 that is less than 0.05 ; therefore, with $95 \%$ of certainty $\mathrm{HO}$ is rejected and it can be said that there is a significant relationship between translation student's Cognitive style FDI and his/her translation achievement and on the basis of positive Pearson correlation coefficient (0.333), there is a linear equation between variables. It means as translation students' Cognitive style FDI increases, their translation achievement increases significantly. $(r=0.333$, sig < 0.05$)$.

An Independent sample t-test is used to test whether if there are any significant differences in translation achievement of students with higher levels of cognitive style FDI compared to those with lower levels of 
cognitive style FDI.

Table 4

Group Statistics and t-test for Equality of Means

\begin{tabular}{|c|c|c|c|c|c|c|c|c|}
\hline & \multicolumn{2}{|c|}{$\begin{array}{c}\text { Levene's Test for } \\
\text { Equality of Variances }\end{array}$} & \multicolumn{6}{|c|}{ t-test for Equality of Means } \\
\hline & $\mathrm{F}$ & Sig. & group & Mean & $\begin{array}{c}\text { Std. } \\
\text { Deviation }\end{array}$ & $\begin{array}{c}\text { Mean } \\
\text { Difference }\end{array}$ & $\mathrm{t}$ & Sig. \\
\hline $\begin{array}{l}\text { Equal variances } \\
\text { assumed }\end{array}$ & \multirow[b]{2}{*}{2.071} & \multirow[b]{2}{*}{0.153} & High & 5.7857 & .89 & \multirow[b]{2}{*}{2.16} & \multirow[b]{2}{*}{6.95} & \multirow[b]{2}{*}{$.000^{*}$} \\
\hline $\begin{array}{l}\text { Equal variances not } \\
\text { assumed }\end{array}$ & & & Low & 3.6163 & 1.1 & & & \\
\hline
\end{tabular}

As can be seen in Table 4, the mean scores related to translation achievement of students with higher levels of cognitive style FDI and those with lower levels of cognitive style FDI are 5.7857and 3.6163 respectively. The meaningful level of the test is less than 0.05 ; therefore, with $95 \%$ of certainty $\mathrm{H} 0$ is rejected and it means that there is a significant difference between the translation achievement of students with higher levels of cognitive style FDI and those with lower levels of cognitive style FDI. Based on the mean score of the variables, it can be said that the grade of translation achievement of students with higher level of Cognitive style FDI compared to translation achievement of students with lower level of Cognitive style FDI, is more and bigger.

\section{Discussion and Conclusion}

The current study was done to examine the relationship between Cognitive style FDI and Translation achievement. The results of the research questions indicated that the translation students who believe in their own way of translation and not fate or chance, performed better and are more likely to succeed and it also supported the fact that translators who can perceives information analytically and are able to analyze and isolate relevant details are more successful in task of translation. The findings of this study also illustrated a significant difference in translation achievement of those who believe in their own ability to succeed (Field independent) compared to those who believe in external clues in order to succeed (Field dependent). It was found that Field independent translation students (Cognitive style) are superior to Field dependent translation students with regard to translation achievement. A lot of researches have been done on the relationship between academic achievement and education or language learning. So it is rather difficult to link the findings of current study with the related literature. However, it is tried to consider translation achievement as a construct that is similar to academic achievement in general (Ghonsooly-Moharer, 2012).

\subsection{Implications}

The strong association between Cognitive style and academic achievement and translation achievement is in agreement with Khodadady and Zeynali (2012), Adelina Guisande, Páramo, Tinajero, and Almeida (2007), Yousefi (2011), Tinajero and Paremo (1998), Maghsudi (2007), Nosratinia and Adibifar (2014), Jack Block et al. (1998) and Jon-Chao Hong et al., (2012). Khodadady and Zeynali (2012) concluded that Field-independent participants outperformed field-dependent participants in IELTS listening comprehension and all of the listening tasks. Therefore, Field independents can perceive objects as separate from the field. Adelina Guisande et al., (2007), also found that field independent children typically showed better performance than field-dependent. Yousefi (2011), similarly found that there was a relationship between cognitive style and listening comprehension and the field independent ones did better on the longer conversations.

Consequently, Field independents tend to be more efficient at retrieving items from memory. Tinajero and paremo (1998), considering the role of sex indicated that, field-independent girls performed better than field-dependent girls and this outcome was not observed for boys. Similarly, Maghsudi (2007) indicated that 
there was a significant difference between dependent and independent students in their English Achievement Test scores and Nosratinia and Adibifar (2014) also found that FI learners outperformed FD learners in their writing post-test. So it supports the fact that Field Independents can dissemble relevant items from non-relevant items within the field and reorganize information better to provide a context for prior knowledge.

In all of the given literature mentioned above the strong link between the findings of this study and the related literature is that Field independent ones performed better than Field dependent ones and spent more time on their academic tasks that led to more academic success. However, in some other areas of literature, the result of current study is in contrast and disagreement with some studies done. For instance, Kheirzadeh and Kassaian (2011) found that there was no difference in the performance of FD and FI students on general listening comprehension and in another similar research Altun-Cakan (2006) showed that there was no significant relationship between cognitive style and academic achievement. The findings of Li-fang Zhang (2003) showed that the Field Dependence/Independence and the thinking style constructs were unrelated. Based on the results obtained in this study, Field independent students did better and outperformed Field dependent students but in some studies done by Olivia N. Saracho (1996-2001), concluded that FD children engaged more in play than did FI ones and Field Dependent teachers received higher ratings than Independent ones so it supports the fact that Field dependents Rely on the surrounding perceptual field.

In conclusion, this study began with the goal of examining the relationship between Cognitive style FDI and Translation achievement and the results demonstrated a positive relationship between Cognitive style FDI and translation achievement of translation students. On the other hand, it means as translation student's Cognitive style FDI increases, his/her translation achievement increases significantly. In general, translation instructors who are familiar with the concepts of Cognitive style FDI can help students in their translation task and student can plan better for their translation process.

\subsection{Suggestions for further research}

The current study involved two universities and is based on the data from Imam Reza University and Khayyam Higher education Institute so, the sample was not very big and the findings cannot be generalized to all other Universities and Higher education Institutes. So for bigger sample it can include more universities and institutes. And in this study a general English text was used as an instrument to measure the translation achievement. The study can be replicated using other genre of translation. And in this study, Cognitive style FDI was linked to translation achievements of students in general. So it can be linked to more specified kinds of translation like literary translation in the future studies.

\section{References}

Altun, A., \& Cakan, M. (2006). Undergraduate students' academic achievement, field dependent/independent cognitive styles and attitude toward computers. Educational Technology \& Society, 9(1), 289-297.

Ausburn, L. J., \& Ausburn, F. B. (1978). Cognitive styles: Some information and implications for instructional design. Educational Communication and Technology, 26, 337-354.

Baker, M. (1998). The routledge encyclopedia of translation studies. London and New York: Routledge. http://dx.doi.org/10.4324/9780203359792

Block, J., Kogan, N., \& Block, J. H. (1998). Parental teaching strategies and children's cognitive style. International Journal of Educational Research, 29, 187-204. http://dx.doi.org/10.1016/S0883-0355(98)00024-X

Dabaghi, A., \& Goharimehr, N. (2011). The relationship between learning styles of field-dependence/independence and integrative/discrete point methods of grammar teaching. World Journal of English Language, 1(2), 79-89. http://dx.doi.org/10.5430/wjel.v1n2p79 
On the relationship between cognitive style and translation achievement of Iranian translation students

Ghonsooly, B., \& Moharer, A. (2012). Examining the relationship between translation students, locus of control and their translation achievement. International Journal of Linguistics, 4(2), 244-256. http://dx.doi.org/10.5296/ijl.v4i2.1796

Guisande, M. A., Páramo, F., Tinajero, C., \& Almeida, L. S. (2007). Field dependence-independence cognitive style: An analysis of attentional functioning. Psicothema, 19(4), 572-577.

Hong, J. C., Hwang, M. Y., Tam, K. P., Lai, Y. H., \& Liu, L. C. (2012). Effects of cognitive style on digital jigsaw puzzle performance: A GridWare analysis. Computers in Human Behavior, 28, 920-928. http://dx.doi.org/10.1016/j.chb.2011.12.012

Kheirzadeh, Sh., \& Kassaian, Z. (2011). Field-dependence/independence as a factor affecting performance on listening comprehension sub-skills: The case of Iranian EFL learners. Journal of Language Teaching and Research, 2(1), 188-195. http://dx.doi.org/10.4304/jltr.2.1.188-195

Khodadady, E. \& Zeynaly, Sh. (2012). Field-dependence/independence cognitive style and performance on the IELTS listening comprehension. International Journal of Linguistics, 4(3), 622-635. http://dx.doi.org/10.5296/ijl.v4i3.2389

Maghsudi, M. (2007). The interaction between field dependent/independent learning styles and learners' linguality in third language acquisition. Interactive Multimedia Electronic Journal of Computer-Enhanced Learning, 7(5), 1-23.

Messick, S. (1984). The nature of cognitive styles: Problems and promise in educational practice. Educational Psychologist, 19(2), 59-74. http://dx.doi.org/10.1080/00461528409529283

Munday, J. (2008). Introducing translation studies (2nd ed.). New York: Routledge.

Nosratinia, M., \& Adibifar, S. (2014). The effect of teaching metacognitive strategies on field dependent and independent learners' writing. Procedia - Social and Behavioral Sciences, 98, 1390-1399. http://dx.doi.org/10.1016/j.sbspro.2014.03.557

O’brein, T. P., Butler, S. M., \& Bernold, L. E. (2001). Group embedded figure test and academic achievement in engineering education. Journal of Engineering Education, 17(1), 89-92.

Pazargadi, A. (1996). The book of techniques of advanced translation. Ghazvin: Obeid Zakani.

Riding, R., \& Cheema, I. (1991). Cognitive styles: An overview and integration. Educational Psychology, 11, 193-215. http://dx.doi.org/10.1080/0144341910110301

Saracho, O. N. (1996). The relationship between cognitive style and play behaviors of three-to-five-year-old children. Personal individual Differences, 21(6), 863-876. http://dx.doi.org/10.1016/S0191-8869(96)00152-3

Saracho, O. N. (2001). Cognitive style and kindergarten pupils' preferences for teachers. Learning and Instruction, 11, 195-209. http://dx.doi.org/10.1016/S0959-4752(00)00028-1

Tinajero, C., \& Paramo, F. (1998). Field dependence-independence in second language acquisition: Some forgotten aspects. The Spanish Journal of Psychology, 1(1), 32-38. http://dx.doi.org/10.1017/S1138741600005382

Waddington, C. (2001). Different methods of evaluating student translations: The question of validity. Translators' Journal, 46(2), 311-325. http://dx.doi.org/10.7202/004583ar

Witkin, H. A. (1964). Origins of cognitive style. In C. Scheerer (Ed.), Cognition: Theory, research, promise (pp. 172-205). New York: Harper \& Row.

Witkin, H. A. (1965). Psychological differentiation and forms of pathology. Journal of Abnormal Psychology, 70, 317-336. http://dx.doi.org/10.1037/h0022498

Witkin, H. A., \& Asch, S. E. (1948). Studies in space orientation I-IV. Journal Psychology, 38, 325-337, 455-477, 603-614, and 762-782.

Witkin, H. A., Moore, C. A., Goodenough, D. R., \& Cox, P. W. (1977). Field dependent and field independent cognitive styles and their educational implications. Review of Educational Research, 47, 1-64. http://dx.doi.org/10.3102/00346543047001001

Witkin, H. A., Oltman, P. K., Raskin, E., \& Karp, S. A. (1971). A manual for the embedded figures test. Palo Alto: Consulting Psychologists Press.

Yousefi, M. (2011). Cognitive style and EFL learners' listening comprehension ability. Indonesian Journal of 
Keshmandi, O., Akbari, O., \& Ghonsooly, B.

Applied Linguistics, 1(1), 70-79. http://dx.doi.org/10.17509/ijal.v1i1.100

Zhang, L. F. (2004). Field-dependence/independence: cognitive style or perceptual ability? Validating against thinking styles and academic achievement. Personality and Individual Differences, 37, 1295-1311. http://dx.doi.org/10.1016/j.paid.2003.12.015 